\title{
Religion and Human Security: The Christian Perspective
}

\author{
Osaji Jacob Olasupo ${ }^{1}$ \\ ${ }^{1}$ Department of Religions, University of Ilorin, Ilorin, Nigeria \\ Correspondence: Osaji Jacob Olasupo, Department of Religions, University of Ilorin, Ilorin, Nigeria.
}

Received: February 28, 2020

Accepted: May 13, $2020 \quad$ Available online: June 23, 2020

doi:10.11114/ijsss.v8i4.4907

URL: https://doi.org/10.11114/ijsss.v8i4.4907

\begin{abstract}
The prevalent security problems the modern state faces justify the current theme for discussion. In the academic circle such that we are witnessing, security or the state of being secured is a necessity for every human being and indeed every living organism. Each organization or group endeavours to provide security for its members be it financial, position, situation, moral, spiritual etc. Security is the most pertinent of all national priorities and plans. However, security as a national programme is not exactly the same in the religious sphere, especially in Christianity. This does not mean that security in Christianity completely runs a parallel line with the security of the nation. In times past people's values were based upon traditional religion and moral principles. However, things are changing fast and despite the proliferation of churches all over the country, values are changing and much emphasis are now placed on the accumulation of physical wealth, injustice, corruption and very high competitive society with lesser religious values and principles especially Christian principles. These have greatly affected the people to the detriment of traditional moral values, resulting in insecurity and peace in our society. The study made use of analytical method for its findings.
\end{abstract}

Keywords: security, human security, religious violence, Nigeria

\section{Introduction}

Nigeria occupies an area of about 923,768, the Nigerian Political Burean with a population of about 150 million people in 2006 "(1), The territory is occupied by more than 350 ethnic nationalities that are found in a fairly well defined location with divergent religious and other beliefs. Religious crisis, conflict, lack of peace, slow development and security problems seem the most recurrent terms gaining wide currency in the 21st century. Human beings value security and harmonious co-existence because they are both a social or global public good. National security and integration of the divergent ethnic nationalities for harmonious living especially in the president Goodluck Jonathan administration of Nigeria, has become the political slogan of our time till today in Nigeria, like other nations of the world is undergoing great economic and technological changes. Today, our beliefs practices and values are shaped by what we see and hear in our society.

This paper seeks to examine security and it's had effects on our national unity. To achieve this, we need to understand what is security and its relation to the Bible. This will lead us to the Biblical concept of security (Old \& New testaments). Religion is about seeking the truth about God and man's justice, as justice is about knowing and doing the right or the truth. Declining confidence in the organized Christian religion is parallel by a loss of confidence in the holy Christian book, the bible (2), The lack of physical instant justice and punishment in Christian religion daily leads to chaining moral values.

The lack of a moral compass along with an increasing emphasis on materialistic goals and selfish individualism, has promoted a culture of greed and indifference to the feelings of others. Some of those that profess to be true Christians use the religion to perpetuate evil and corrupt the society by their evil acts.

In government, business and religious circles today, many have paid scant attention to maintaining high values, this in turn has produced a sense of loss in the minds and hearts of the population in general. In some cases, people claim to have embraced certain high moral values but their character do not necessarily translate into action, moreover some government policies have led to insecurity of lives thereby leading to corruption and accumulation of wealth (3),

\section{Security}

The word 'secure' entered the English language in the 16th century. It is derived from Latin securus, meaning freedom from anxiety. What is security and what does it mean to be secured? The word "security" is an everyday word 
commonly used by persons to describe the situation or a situation of a person, object, group of persons, plans etc. The Chambers Dictionary defines security as the state, feeling or means of being secure, confidence, protection from espionage, theft, attack, etc. It is also a pledge, a guarantee, a surety, the right conferred on a creditor to make him or her sure of receiving a debt etc (4),

Security is freedom from, or resilience against, potential harm (or other unwanted coercive change) from external forces. Beneficiaries of security may be persons and social groups, objects and institutions, ecosystems, and any other entity or phenomenon vulnerable to unwanted change by its environment. Security mostly refers to protection from hostile forces, but it has a wide range of other senses: for example, as the absence of harm (e.g. freedom from want); as the presence of an essential good (e.g. food security); as resilience against potential damage or harm (e.g. secure foundations); as secrecy (e.g. a secure telephone line); as containment (e.g. a secure room or cell); and as a state of mind (e.g. emotional security). The term is also used to refer to acts and systems whose purpose may be to provide security: (e.g. security forces; security guard; cyber security systems; security cameras;remote guarding).

\section{Biblical Concept of Security the Old Testament Record}

Christianity is a religion built upon an already existing national religion Judaism, which is the religion of the nation of Israel. This religion has written records of the events that led to its founding, as well as its progress through centuries. The catalogue of these records are what we know as the Old Testament. The Old Testament is not only about the religion of Israel but also about its history.

When Israel went down into Egypt, it was not as a nation but as a large family of about seventy persons. It was in Egypt that the Hebrews grew into a nation. Yet at this stage, national consciousness and national security was not quite pronounced because they were not in a land they could call their own. When they settled in the promise land, they first existed somehow, as city states, in the absence of a central authority to judge the people, families and tribes felt obliged to take their security in their hands. The book of Judges (19-20) narrates the war between the tribe of Benjamin and the rest of the tribes of Israel and the great slaughter that resulted from the war. This war was fought because there was lack of internal security or better put organized internal security. However, the other tribes acted in unison so as to arrest the situation and avoid what the men of Gibean had done to the wife of the Levite. Let it be noted that at the early stage, Israel was under the Judges. It was not by family succession or inheritance that any one became a judge but by divine choice. The judges in their time or in times of need (national protection against external aggression) were chosen and they performed their duties. In short, Israel having settled in the Promised land, grew more or truly security conscious, hence their demand for a king "... now appoint for us a king to govern us like all the nations"1 Sam 8:56. What was the basic reason for the deman for a king> the same chapter of the first book of Samuel gives us the answer to the question. In addition to Israel being like the other nations, the people added " . . that out king may govern us and go out before us and fight our battles," (1 Sam 8:20). So the protection of territorial integrity was underscored in the demand for a king.

\section{Biblical Concept of Security: The New Testament Writing}

Christ neither preached for nor preaching against nation security. He made allusion to kings who before going to war should sit down and calculate and examine their weaponry so as to decipher if they can successfully execute an impending war or make peace.

Christ did not teach about national security because his kingship was not of this world, and not from this world... and not from this world (John 16:36). Thus he had no army to train or even bodyguards to guard him. Yet he preached of a kingdom. He said, “... as my father appointed a kingdom for me, so do I appoint for you that you may sit and drink in my kingdom, and sit on thrones judging the twelve tries of Israel"(Luke 22:29-30).

\section{Jesus and Security}

\section{Health security}

The gospel narratives are replete with healing miracles. Jesus healed the centurions servant who was lying paralyzed and was in terrible distress at his masters house (Matt. 8:5-13). He cured Simon Peter's mother-in-law of high fever (Luke 4:36-39). He healed a woman who for twelve years suffered from haemorrhage. (Matt 9:20-33) Lepers were cleansed (matt 8:2). These are only a few of them.

\section{Mental/Spiritual Security}

The mentally ill and possessed were freed and made whole. Here we recalled among others, the Geresene demoniac who said his name was Legion because he was under the influence of many demons (Luke 8:26-37) Jesus cast out of Mary Magdalene seven demons (Luke 6:20).

\section{Accidental and Natural Infirmities}

Infirmities like blindness, deaf, dumb, etc were cured by Jesus. Mark 8:22 tells us of a blind man at Bethsaida who was 
brought to Jesus by some people so that Jesus would cure him of the blindness, this was done to him in Mark 10:36-52 what about the popular story of Bartimaeus who could not stop shouting until Jesus heard him and had pity on him and cured him of his blindness in Mark 7:31-37 the work also revealed how Jesus healed a deaf and dumb man to the amazement of the people who saw it.

\section{Security Against Natural Disaster}

Jesus provided security against natural disaster. He calmed the stormy sea (Mk 4:35-41 Mtt 8:23-27, Lk 8:22-25)

\section{Security against hunger}

Jesus not only used parables to teach about hunger, he on two occasions multiplied loaves and fish to feed thousands of people (cf Lk 9:10ff, John 6 1ff).

\section{Marriage and family security}

Jesus protected the sanctity and indivisibility of marriage contrary to what was obtained by then (Matt 19:1-9, Matt 5:31-32).

\section{Security against injustice and Jungle justice}

The women caught in the act of committing adultery was brought to Jesus. He did not condemn her neither did he support her adulterous life (Jn 8:1-11). He saved her from been stoned to death by the people.

\section{State of Financial and Economic Security}

In Lk 20:20-26, we came across the famous dictum “... give to Caesar what is Caesar's and to God the things that are God's. this was in response to the question of the Jews paying taxes. This was a plot to track Jesus down. A straight yes answer would have meant supporting the Roman conquerors against his Jewish brothers, and a no answer would have meant acting and encouraging the Jews against the Roman authority. Thus, by this act he permits his followers to make their own financial contributions/taxes to the state. The gospel according to St. Matthew records in chapter 17 verse 24-27 that Jesus and Peter paid the temple tax. This was done in a miraculous way.

From the above we can see the sorts of security Jesus provided. He would not advocate for not promoting military security because according to him the son of man (meaning himself) came that we many have life and have it abundantly (Jn 10:10) and he also made it clear that the son of man came not to be served but to serve and to give His life as a ransom for the many that will accept His salvation (Mk 10:45). Thus we infer that Jesus was a soldier of a special type who came to seek and save the lost (Lk 19:10).

\section{Security in the Apostolic Era}

We recall that in the night of the Thursday in which Jesus was arrested one of the apostles made use of his sword to fight for Jesus security. He drew his sword struck and caught off the right ear of a high Priest whose name was Malchus. The apostle in question who was anonymous in Matthew's gospel was Peter the head of the apostles (Matt 26:51-52. In 18:3). Throughout the earthly life of Jesus, it was this one and one only time that sword was used. Even at this crucial moment when naturally the instinct of self preservation would have warranted the use of weapons-(defensive weapons). Jesus demanded that the sword be sheathed. He then made it clear that all who take the sword will perish by the sword. This teaching of Jesus that all who take the sword will perish by the sword seemed to have greatly influenced the apostles, hence in the apostolic era as well as the post apostolic era. Instead of fighting to secure their lives. Christians ran for safety. This was also in obedience to the instruction Jesus gave them that if they were pursued in one town. They should run to another for safety (Matt 10:23).

St. Paul admonished the early Christians to be subject to the governing authorities, because God is the ultimate source of all authority. He went further to advocate that the Christians pay the authorities their taxes and dues (Roman 13:1-7). This clearly shows that though the followers of Christ did no enlist in the army did not carry weapons to defend themselves and their new religion, yet they supported the government in other matters of security thereby enhancing good governance. Prayed for the leaders (Government), and contributed financially to the smooth running of the government of their day.

\section{The New Church Teaching on Security}

As we have noted all along, the security which Christianity provides is not that of weapons of destruction to kill and terminate life. But of spiritual and moral security and solidarity with the poor, the afflicted, the sick and the needy of our society.

Quite well, the concept of security in Christianity is the belief in the security provided by God the father through Christ i.e. the divine assistance, which God provides us and the life of the love and charity which the Christians provide one another in solidarity. This is with that we live in a transient world, that our real home is heaven. Christianity upholds 
social justice as security for the society.

As if recalling the words of Cyrian to the bishops of Numbia, the Vatican Council II in the document- The Church in modern world (Gaudium at spes) holds that: The joy and hope, the grief and anguish of the men of our time, especially of those who are poor or afflicted in anyway, are the joy and hope, the grief and anguish of the followers of Christ as well... that is why Christians cherish a feeling of deep solidarity with the human race and its history. The social solidarity of the church has had advantageous effects on the individuals, economically, morally etc Christian believe that God is the ultimate security, the world is not our permanent home, hence, we should not see it as the source and summit, the end of all our being and forget our God because we want to enjoy the world. Apart from God we can do nothing. "Unless the Lord builds the house, in vain do its builders labour. Unless the Lord guards the city, in vain does the watch man keep vigil" (Ps. 127:1-2).

While still holding to her traditional position, the church, since the end of the $19^{\text {th }}$ century, has turned to give the world a new social teaching regarding justice and fairness in the world. This goes beyond eloquence at the pulpit. However, it still hangs on the rights and privileges of the oppressed workers, to give them a sense of belonging

Although the church is not such a political organization or stat, yet it cannot stand aloof from politics because it has a divine mandate to defend the eternal values of moral and religion relating to all aspects of private and public life (Eugene H.)

In the $19^{\text {th }}$ century, following the industrial revolution, workers were hired to work for lengthy hours and were systematically exploited, being over-used. Church leaders in Europe and America made their observation and in 1891 Pope Leo XIII came out with the document "Return Novarum." The heart of the problem was "the misery and wretchedness pressing so unjustly on the majority of the working class 9 (Reru, Novarum 2). The very rich few have laid a yoke, which almost totally enslaved the poor labourers. Labour and wage should be commensurate. Wages should not be just enough for one to lead a frugal life of hand to mouth, one may say.

Since the appearance of Rerum Novarum by Pope Leo XIII, other pontiffs have added heir voice to the social problems of peace and social justice, closing the gap between the rich and the poor. The poor are not meant to eat of the leftover of the rich but have a right to a fair share of the earth's resources. These lead to tranquillity and security both at the national and international levels.

\section{National Security}

The concept of security of a nation goes back to the cradle of nation-states themselves. Armies for domestic peace-keeping and maintaining national sovereignty have existed since the dawn of recorded history (5),. Civil and national police forces have also existed for millennia. Intelligence agencies and secret services and governments stretch back to antiquity such as the Roman Empire, Benin Kingdom, Bornu Empire among others in Asia (6),. While the general concepts of keeping a nation secure are not new, the specific English term "national security" itself came into common parlance in the 20th century (7),. Methodologies and strategies to achieve and maintain the highest possible desired state of national security have been consistently developed over the modern period to this day. However, the concept of national security is very difficult to define because the roof term, security, has remained a contested concept. In other words, it has no universally accepted definition due to its many-sidedness arising from ideology and timeframe being addressed, as well as the focus of analysis (8),. Moreso, the issue of national security is so critical to nations and national interest. Hence Walter Lippmann observed that a nation is secured to the extent that it is not in a question to lose core values, life, property and liberty(9),. National security also refers to the requirement to maintain, the survival of the nation state through the use of economic, military and political power and the exercise of diplomacy (10), President Olusegun Obasanjo, while presenting his grand strategy, declared that the primary objective of national security shall be to strengthen the Federal Republic of Nigeria, advance her interest and objectives; to contain instability; control crime, eliminate corruption, enhance genuine development, progress, growth, improve the welfare and well-being and quality of life of the citizenry (11),. In this work, we shall, be adopting Gwarlox definition which sees national security as freedom from hunger, or from threat to a nation's ability to protect and defend itself, promote its cherished values and interests, and enhance the well-being of its people (12). From the above definition, it can be observed that national security is not restricted only to weapons and military preparedness but encompasses political, social and economic well-being of the people. As such, any threat to any of these, constitutes a threat to national security.

\section{The Significance of Religion in Nigeria}

In Nigeria, as in other countries of the world, religion plays a very vital role in the lives of the people. According to Abogunrin (13), religion to a large extent influenced the economic, social and political developments of the nation. Religion is so significant in Nigeria to the extent that any leader whether military or civil cannot disregard it. Nigerians 
today have come to hold strongly to the fabric of religion as the only trustworthy assurance to life. God's laws cannot be disregarded. The bible is a full book and its laws and doctrine gives hope and a better life. Dzurgba (14), says that government and God are the authorities who command and forbid certain actions as the case may be in religion. God commands obedience to positive moral principles and forbids obedience to negative moral principles.

There is also the strong belief in traditional religion that God (gods) reward good character and punishes bad character or disobedience in the community. Idowu (15), wrote that Jakuta was the Yoruba way of conceptualizing the wrath of Olodumare (God) against all forms of wickedness. God whatever name he is called in different tribes with his lieutenants gives out instant justice in proportion to one's character in traditional religion.

In electoral process of this nation religion has played a very prominent role. It is easy to see at a glance that muslims vote for an Islamic believer while Christians likewise vote for a Christian believer. Takaya(16), said that religious politicization in Nigeria only grows deeper such that both Christian and Moslem leaders tend to weigh every government decision in terms of their deceptive religious, calculating heir gains and losses. It is difficult if not impossible to find voters gaining the votes of those of other faith. This pattern is also adhered to in language and tribe.

The significance of religion to the peace and good governance of a nation cannot be over emphasized, in view of the fact that man does everything rigorously and it permeates all aspects of human activity. Idowu (17), says that religion is very much and always with us. It is with us at every moment of life - in our inner most beings and with regards to the great and minor events of life. Bouquet (18), said that religion cannot wisely or safely be ignored or neglected as it is by many frivolous persons today, even a defective or obsolete scheme of religion will serve the individual better than none at all. Religion is as old as man himself its relevance in our lives is new every morning from birth to death, one observes religion at every stance of life.

Nigeria, like many nations of the world celebrates Jesus Christ at Christmas time (Birth of Christ) and in Easter time (Death and Ressurection of Christ) and Muslim festivals of Eid-el-Kabir and Eid-el-Fitri. Public holidays are declared by the government to celebrate such festivities. Also, in traditional religion, countless festivals are observed in celebration of different events, divinities and ancestors, e.g. Osun-Osogbo. Religion has played a very prominent role in the decision and policy making process in this country as in other parts of the world.

Nigeria is experiencing a phase of churches springing up daily. Most of the men of God claim to have been called by God are of questionable characters and their so dedicated members, how dedicated are they? According to Isola A and Ayegboyin D. (19), it is a fact that Christianity in Nigeria is a widely scattered family of denominations, all of them professing some kind of faith in Christ but how sincere are they? Religion has now become the hope of the oppressed and poverty stricken individual in a depressed economy like ours.

\section{Conclusion}

The concept of security in Christianity has to do with the spiritual, moral and economic well-being of the individual, of the less privileged the hungry etc and the upholding of the dignity of the person which in turn provides order, peace, justice and fairness in the society. Spiritual security has given the people courage against witchcraft and other acts of the medicine man and woman and has helped many to withstand occult evil (spiritual) attacks. Prayers are often offered to God for the security and well-being of the nation and our different communities.

The moral, economic, health etc well-being of the citizens: these Christianity provides through the provision of schools and education, a moral balanced and God fearing upbringing, provision of hospitals, peace negotiations and peaceful demonstrations.

From the above, I have shown that the concept of security in Christianity is one that trusts God for protection against spiritual evil, security based on God's protection from moral evil, security from isolation and segregation, security that seeks to promotes egalitarian society, love that helps to down tools and weapons of war, love that brings harmony, acceptance and unity among people in a community large or small, love that builds and uphold human dignity. That is the concept of security in Christianity and that is the stand of Christianity in national security

\section{Recommendation}

Nigerians need to go back to God in prayers of repentance because our concern for God is already waning. Everyone should be concerned about the fact that Nigerian's security problems lie with God who is able to grant absolute security.

The socio-political economic and moral organs of the nation should make a right turning to God. Every individual should thirst for God's intervention. Every Nigerian should cry against evil so as to build a more secure and buoyant nation.

With regards to economic and financial corruption, everybody in this country should endeavour to reduce to the barest minimum all greed tendencies. What is meant for all should not be found with the few corrupt. The nation's treasury in 
every public servant and political office holder's care should not be looted. Corrupt officials in Nigeria are voracious locusts in the field. This destructive drive to be rich by all means must be addressed personally and generally. We should learn to be considerate. Let all have it in mind that they keep their neighbours' welfare.

The government and all security organs should be red alert to security crime as the antecedent of crime is insecurity. Assassins and robbers are just in every street looking for their next victims. The indelible memories of sadness they leave in victims heart can't fade easily. Priority should be given to the protection of lives and properties of Nigerians from robbers and assassins who are locusts of a sort by the government.

Furthermore, ethnocentrisms and tribal conflicts cannot make a nation progress. Nigerians should be educated that the fact that, we are of different tribes and we speake different languages does not mean our unity should be cut off. Our tribal diversity should be our unity.

In religious circles today, many have paid scant attention to maintaining high moral values in our society. This in turns has produced a sense of loss in the minds and hearts of the population. In general, religious insincerity and greed have made government and church leaders unable to solve their biting problems and help to members. Dzugba (20), says that, instead of negative confrontation, the church should perform the positive function of safe - guarding law and order, security of life and property, ensuring that there is peace and stability, protecting human rights and freedom, right democracy, enhancing cohesion and solidarity as well as promoting equity and justice in the society.

A grave danger or scandal in churches today is the issue of money. This has led to the split of churches or the rise of new ones. The church's mission of conscientization should start from within. According to Afuba (21), when the interventionist actions of the church in the public space flow easily and directly from the principles of its internal policies the voices of the church will inexorable, command greater authority and acceptance. At this time of corruption and favouritism, the church could lead the way in conscientization by being more discriminating in its acceptance of denotions and bestowal of honours. Where donation seem to be above the legitimate means of donors and character visibly questionable, the church should reject all such donations and stop awarding honours to them, this would inspire the faithful to go out and uphold high ethical and moral values in the larger society.

In our society today, many children are victims of family break up. Others have parents who have little time for them. Thousand of our young ones have grown up with inadequate moral and family guidance. Practical institution and education should be provided by the church in order to train people to love righteousness and rebuff evil. This will lead to a peaceful and healthy society. There is the need for churches to speak sincere prophecies and support the genuine needs and aspirations of its people (22). Ikeke" asserts that all the unjust and obnoxious laws that have been promulgated in Nigeria to strangulate the people are all part of public policy. Public policy is a strong force for the making, construction and reshaping a society. The church should not support the bad policy of government, they should not shy away from the truth. Moreover, the church should acknowledge the culture sociological and spiritual experiences of their members seriously.

\section{References}

Abisoye, S. A. (2001). Basic Text on West Africa Traditional Religion. Oyo Immaculate Publishers.

Abogunrin, S. O. (1999). Religion and Democarcy in Nigeria, Ibadan: ORITA. Journal of Religious Studies, 1-2

Adams, N., \& Beatrice, N. (2009). Harmonious Attitude in Social Psychology Brelton: Hodder and Stoughton (pp. 316-319).

Admas, B. T. (2007). Civilizing Religious Society. Cambridge: University Press. pp.118-120

Afuba, I. (2006). Sunday Independent” The Nigerian Project: What Role for the Church Vol 2 No 22

Animoshe, D. "Introduction to Security and Insecurity Threats in Nigeria" New Nigeria Monday September $9^{\text {th }}$ September.

Bostman, N. (2006). The Historical Background of National Security and Interest in Ancient Europe. New Jessey: NEWTON Corporation, Armalda, pp. 26.

Dorr, D. (1992). Integral Spirituality. Dublin: Gill and Macmillan Ltd.

Dzurgba, A. (1999). The Role of Religion in the Political and Ethical Re-Orientation of Nigerian Society. ORITA. Journal of Religious Studies, 11-2.

Gwarzo, I. (1998). Meeting the Current Challenges of National Security National War College.

Idowu, B. (1977). African Traditional Religion-A definition. London : SCM Press Limiting.

Ikeke, J. M. (2005). Ethnic Justice Warri. Snaps Press Limited. 
Ishola, A., \& Aiyegboyin, D. (2000). Re-discovering and Fostering Unity in the Body of Christ- The Nigerian Experience. Ibadan: Sceptre Prints Limited

Kenny, J., \& Bouquet, J. (2000). The Church- a light to the Nation" Ishola A. and Aiyegboyin D (ed) Rediscovering and Fostering Unity in the Body of Christ- The Nigerian Experience.

Nigeria political Bureau 1989 Reports on Ethnic and Tribes in Nigeria, National Workshop on Ethnicity Stability and Development NPB Series XX1.

Ojularin, A. B. (1995). The Dynamics of Inter and Intra Ethnic Relations in Nigeria. Ibadan: University Press, Ibadan pp. 18.

See Adu, J. An assessment of National Security in the Forth Republic 1999-2007 in law and National Security in the $4^{\text {th }}$ Republic Lapai Democarcy Series Talla N. Sunday and Reuben.

Takaya .(2005) Religious politicization, The Nigeria Experience: New York.

Thomas, I. (2000). “Threat Assessment” Lecture Delivered at National War College Jaji Nigeria.

\section{Copyrights}

Copyright for this article is retained by the author(s), with first publication rights granted to the journal.

This is an open-access article distributed under the terms and conditions of the Creative Commons Attribution license which permits unrestricted use, distribution, and reproduction in any medium, provided the original work is properly cited. 